Дамир Ј. Смиљанић

\title{
РЕЧ ,ЈА“ ИЗМЕЂУ ХИПОСТАЗЕ И РЕДУКЦИЈЕ ПРОБЛЕМИ ФИЛОЗОФСКОГ ГОВОРА О СОПСТВУ
}

У раду аутор промишља статус речи ,ја', односно ,сопство“ у филозофији. Разликујући две тенденције опхођења према проблему самосвести - идеалистичку и аналитичку - он указује на два начина поимања сопства који се међусобно разликују. Идеалисти хипостазирају сопство у засебан ентитет „Ја“ који у немачком идеализму (нпр. код Фихтеа) постаје принцип саме филозофије; с друге стране, аналитички филозофи критикују такву супстанцијалистичку употребу речи везаних за самосвест и субјективност и редукују ту употребу на ситуацију једног лица које себе препознаје као ,ја“. Уместо да оптира за једну од ових перспектива поимања сопства, аутор се са становишта метафилозофије залаже за проширење семантичког хоризонта речи којима се користимо у филозофији. На крају чак предлаже да се у анализу сопства укључи и афективно-патичка димензија искушавања сопствене субјективности, у којој ће реч ,мене' (или ,мени') имати важну улогу.

Кључне речи: ја/Јa, сопство, идеализам, хипостаза, аналитичка филозофија, редукција, метафилозофија, језичка игра, мене

\section{УВОД}

Као последица „лингвистичког обрта“ у савременом добу филозофија је постала скептична према сопственој појмовности. Појмови, који су мање или више некритички били у оптицају у оквиру традиционалне метафизике (појмови као што су бивство(вање), суштина, душа, бесмртност, бог итд.), доспевају у фокус језички мотивисане критике и бивају кориговани или чак елиминисани из филозофског дискурса кројеног према мерилима лингвистички освешћене 
филозофије. Оставимо по страни проблем да ли је одиста сва метафизика бесмислена, као и уопште оправданост доношења суда о валидности старијих филозофема према критеријима, који се тичу језика, а који су устаљени тек са еманципацијом језика као кључног предмета филозофије. У сваком случају, последица обрта ка језику је повећан опрез приликом тематизације типичних филозофских појмова.

Један од тих појмова је и онај без којега је незамислива трансформација метафизике која се одиграла у новом веку, која је започела са Декартом, а коју је Кант означио као „коперникански обрт“1 - појам ja или ego. Ако се став Cogito, ergo sum сматрао својеврсним почетком нове оријентације у филозофији, онда би се критика самозаснивајуће субјективности могла сматрати последицом новог заокрета, до којег је дошло у модерном добу. И одиста - са Ничеом² почиње низ покушаја да се „децентрира“ субјект (у двоструком смислу: да се избаци из центра филозофије али и да се промисли његов нестални карактер) који ће свој врхунац достићи изван филозофије: у Фројдовој психоанализи, где субјекат дословно и симболички - није више „газда у својој кући“. У самој филозофији је управо критика језика допринела децентрирању субјекта - говор о „ја“, „сопству“ и еквивалентним терминима се радикално преиспитује. Посебно је тзв. аналитичка филозофија отишла далеко у преиспитивању традиционалних филозофских представа о субјективности и начину њеног именовања и описивања. Изнова наоштрени „Окамов бријач“ је тако нерефлектованом субјекту дословно дошао главе.

На наредним странама ће бити размотрена мотивација аналитичке критике субјективности (својеврсни reductio subiecti ad absurdum) као и питање у којој мери је она оправдана. Као непосредни повод за ово разматрање служи недавно објављен текст Ансгара Бекермана, новијег представника аналитичке оријентације у немачкој филозофији, у којем критикује инфлаторну употребу речи ,Ја' и ,Сопство“ у филозофији. С обзиром на датум објављивања тог чланка, очигледно је оваква врста критике субјективности још увек актуелна. Да ли је одиста „Ја“ постало опсолетно или ипак писање те речи великим словом

1 Тим обртом је маркиран прелаз од објекта ка субјекту (сада субјект конституише објект, а не обратно). Упор. Критика чистога ума: В XVI-XXII.

2 У суштини већ са позним Фихтеом и Шелингом (после 1801. године) односно са Шопенхауером: тамо се откривају пукотине у концепцији самосвесног и сувереног „Ја“ које није искључиво одређено (раз)умом и које измиче саморефлексији. 
може имати смисла, једно је од важних подпитања која овде треба одговорити евентуално чак и преиспитати. После приказа аналитичке критике метафизичког хипостазирања сопства поставиће се кључно питање: која концепција сопства је уверљивија, да ли она идеалистичка или она аналитичка. Уместо пристрасног одговора на то питање аутор ће га размотрити са метафилозофског становишта и расветлити језичко-семантичку позадину супстанцијалистичких и редукционистичких погледа о сопству. На тај начин ће се покушати разумети недовољно истражена логика језичких игара, из којих се у суштини састоји филозофија. Напослетку аутор не искључује могућност да постоје алтернативни видови промишљања субјективности који би се артикулисали с оне стране хипостазе и редукције сопства које су досад обележиле „еголошки“ дискурс.

\section{СОПСТВО КАО СУПСТАНЦИЈА}

Савремена аналитичка филозофија језика наставља традицију номиналистичког мишљења. То се види посебно на критичком ставу према хипостазирағу термина ,jа“ и ,сопство“: оно што је дато у рефлексивним радњама самоодношења (примери: „Перем се“, „Чешљам се“, „Радујем се“ ...), а што се без проблема може описати уз помоћ рефлексивне заменице, разматра се посебно, као засебни елемент искуства. Постоји један аргумент који се често користи у таквим ситуацијама - приговор супстанцијализащије. (На немачком се као још „јачи“ термин користи „постварење“ [Verdinglichung], рецимо код Адорна и других марксистички оријентисаних аутора.) Класичан пример супстанцијалистичког поимања субјективности може се наћи код Декарта, који заступа тезу о двема засебно постојећим супстанцијама: res extensa и res cogitans. О хипостази се овде ради из тог разлога што се спаја оно што је категоријално неспојиво: ствар и мишљеље (типичан пример „категоријалне грешке“汭. Наравно, у одбрану Декарта би се могло рећи да он термин , res “ не схвата у смислу материјалних ствари, него у специфичнијем (онтолошком) смислу, еквивалентно општој категорији, нешто' Па ипак је симптоматично да се овде користи израз који се примењује и за означивање материјалних

3 У традицији аналитичке филозофије је посебно Гилберт Рајл своју критику западноевропске метафизике градио на разоткривању такве врсте грешака [categorymistake]. Упор. Ryle 1951: 16 и даље. 
ствари. Иако је поента картезијанске диференције између две супстанције да се оне не могу свести једна на другу, идеја материјалности као оног примарно супстанцијалног је имплицитно имала утицај на формирање идеје о „Ја“ као мислећој супстанцији.

Занимљиво је да је чак и у духовној оријентацији супротној оној каретезијанској, наиме у емпиризму, заступана слична идеја о супстанцијалном карактеру „сопства“. Тако Лок у Огледу о људском разуму даје следећу дефиницију сопства: „Ја‘ је она свесна мислећа ствар [sic!] која (ма од које супстанције била састављена, духовне или материјалне, просте или сложене) осећа задовољство и бол (односно свесна је једног и другог), која је кадра да буде срећна или несрећна, која се дакле брине за себе онолико колико обухвата њена свест.“ (Лок 1962: 365 и сл.) Аналогно материјалним стварима као носиоцима својстава и „Ја“ се поима као носилац свести. Оно се изричито одређује као „мислећа ствар“. (У оригиналу одиста стоји „, thinking thing“.) Но ипак је Лок опрезан када гаранцију за лични идентитет не проналази у истоветности супстанције, него у истоветности свести. Сопство (код Лока се одиста користи израз , Self ) је идентично самом себи зато што има свест о себи. Слично о „Ја““4 размишља и Баркли у својој Расправи о начелима људске спознаје: „Оно што сам ја сам, што означавам изразом $j a$, исто је као и оно што се мисли под душом или духовном супстанцијом.“ (Berkeley 1999: 79) Други емпиристи неће следити ту тезу о личном идентитету ( $\mathrm{a}=$ духовна супстанција). Тако ће нпр. Хјум оспорити карактер јединствености сопства и претпоставити да је оно нешто диспаратно, у себи расцепкано [,, a bundle or collection of different perceptions "].

Немачки идеалисти су били на трагу опасности коју са собом доноси супстанцијализација сопства. То показује већ Кант у „Паралогизмима чистог ума“, где указује на проблематику супстанцијалног карактера душе у контексту тзв. „рационалне психологије“. Према Канту, „ја“ уопште није појам, него обична свест која прати све појмове (упор. Критика чистога ума: В 404). Па ипак је и овде реч о „синтетичком јединству аперцепције“ - јединство остаје главно обележје самосвесне субјективности. Корак даље од Канта је у „осамостаљивању“ Ја отишао Фихте, код којега оно постаје својеврстан

4 Енглески изрази ,I“ и , Self‘ се овде користе као синоними. (Занимљиво је напоменути да се на енглеском ,jа“ увек пише великим словом!) 
принцип филозофије. ${ }^{5}$ Према његовом мишљењу филозофија не полази од чињенице, него од делотворне радње [Tathandlung] „тј. од чисте делатности која не претпоставља никакав објект, него га сама производи, и где деловање, према томе, непосредно постаје дело“ (Фихте 1976: 143). „Ја“ није као код Канта нешто што само прати одређене менталне радње, већ је само по себи посебна врста радње: она радња која је уједно резултат те радње. Према Дитеру Хенриху, једном од најбољих познавалаца филозофије немачког идеализма, Фихтеова заслуга лежи у указивању на специфичан карактер самоосвешћивања Ја који не треба да се поима према „циркуларном“ моделу рефлексивне теорије самосвести, у коју је западала пред-фихтеанска филозофска мисао (види Henrich 1967). Својим инсистирањем на делатном (можда би се чак аналитички могло рећи: вербалном) карактеру искушавања Ја Фихте је припремио терен за поимање сопства као заједничког имениоца свих чинова самоодношења, чиме је избегнута његова супстанцијализација. Онај ко Ја поима као ствар, била она мислећа или не, према Фихтеу запада у грешке догматизма (догматизам у смислу материјализма). Али оно што ће из аналитичке перспективе и код Фихтеа остати дискутабилно јесте чињеница да „Ја“ пише великим словом.

Без обзира на „тренд“ десупстанцијализације Ја, онако како се одвијао после филозофије немачког идеализма, а који се између осталог препознаје у натурализащији свести, проглашавању сопства епифеноменом, не треба из вида изгубити покушаје рехабилитације „еголошких“ истраживања у модерној филозофији, најконсеквентније изведен у Хусерловој феноменологији. Ego и eidos су овде опет у уској вези, наравно не као у Декартовој или Фихтеовој метафизици, али поново у трансценденталном руху. Тако на једном месту у Картезијанским медитацијама Хусерл говори о Ја као „супстрату хабитуалности“ (Husserl 1987: § 32). И Хусерл пише ,jа“ великим словом. На тај начин се још једном потврђује афинитет трансцендентално оперишуће филозофије ка супстантивистичком поимању субјективности. Но нови успон трансценденталног Ја није дуго трајао ...

5 Тако рани Шелинг, који је још под јаким утицајем Фихтеовог трансценденталног идеализма, једном свом спису даје програматски назив „Ја као принцип филозофије или о ономе што је у људском знању неусловљено“. Упор. Шелинг 1988: 35-128. 


\section{АНАЛИТИЧКА КРИТИКА ХИПОСТАЗЕ СОПСТВА}

Аналитичка филозофија је од својих почетака развила резерву, дистанцу и отворену аверзију према сваком - било манифестном, било скривеном виду метафизике, могло би се чак рећи и извесну фобију од таквог начина размишљања. У контексту одбацивања метафизике и њеног језика, који не испуњава критерије сувислог говора, један од појмова, чија непромишљена употреба је такође постала предметом жестоке критике, јесте реч „Ја“ односно „Сопство“ (велико слово!). Оно што се углавном критикује јесте одвајање те речи од оне особе која је употребљава у конкретном говору како би њоме означила себе и тиме се одредила наспрам других субјеката (особа). Штавише, као што показује необична употреба те речи код Фихтеа, она се чак користи у трећем лииу једнине: „Ја поставља изворно своје сопствено бивство“, „Ја поставља Не-Ја као ограничено кроз Ја“, „Ја поставља само себе као ограничено кроз Не-Ја“. Тиме је употреба речи ,ја“ доведена до апсурда: ја више нисам ја, него оно!

Али аналитичко промишљање проблема епистемичког и онтичког статуса сопства се не своди само на елиминацију његове супстанцијализације, него има и те како и позитивне аспекте. Тако се у разним аналитичким теоријама самосвести и субјективности изнова промишља проблем личног идентитета (види Perry 2008), поставља се проблем qualia као најсубјективнијих елемената свести (оно што се не може редуковати на процесе који се одвијају у самом мозгу, интеракцију можданих ареала итд.), разматра се напуштање сопствене перспективе посматрања стварности и потенцијално преузимање туђих перспектива, потпуно неупоредивих са оном првом, могућност удвостручавања и уопште мултипликације сопства итд. Занимљиви аргументи, испробавање разних углова посматрања, необични мисаони експерименти (покушај размене тела и сл.) доминирају аналитичком дискусијом о проблемима сопства. Израз ,ja‘ се овде користи сасвим скромно у функцији личне заменице (без обзира што се у енглеском израз пише великим словом!). Уместо израза ,сопство се пре користи израз ,особа', чиме се избегавају могуће метафизичке конотације којима је у традицији била оптерећена употреба првог израза.

Исправност таквих тенденција заговара и један од главних представника 
аналитичке струје у немачкој филозофији, Ансгар Бекерман, сада већ пензионисани професор филозофије из Билефелда. Он у свом недавно у часопису Information Philosophie објављеном чланку „Не постоји Ја, постојим само ја“ [, Es gibt kein Ich, es gibt nur mich “] критикује проширену употребу одговарајуће личне заменице, онако како је налазимо у традиционалној метафизици. „Реч ,ja‘ је као лична заменица (а) сингуларни израз који се односи на појединачне предмете (особе); она је (б) индексички израз чија референца се мења зависно од контекста изражавања и односи се (в) увек на оног ко исказује тај израз односно ко поима одговарајућу мисао.“6 (Beckermann 2012: 36) Међутим, ако се каже то или оно Ја, то или оно сопство, једно сопство и сл. ${ }^{7}$ онда се те речи погрешно употребљавају, оне у том случају означавају родне појмове као што су именице ,пас', ,књига' или ,кућа‘. Иако није против увођења нових термина у филозофски дискурс (па чак и у свакодневни говор), Бекерман сматра да је оваква употреба речи ,ја‘ или ,сопство“ непотребна и контрапродуктивна. Не треба нашу већ устаљену граматику и семантику допуњавати новим правилима или изразима - тиме се само непотребно компликује језик којим се служимо у филозофији. Како би илустровао те компликације, Бекерман наводи низ по његовом мишљењу неразумљивих исказа: „Sum res cogitans“, „Ја не постоји“, „Ја сам нико и ништа“, „Ја је илузија коју ја сам у сваком тренутку могу произвести“" итд.

Конкретну корист од избегавања говора о засебном супстрату званом „Ја“ или „Сопство“ и задовољавања употребом личне заменице ,ја“ Бекерман види у могућности да се боље разумеју нека стања ствари која обично остају непрозирна док се инсистира на супстанцијалистичком говору. Тако он узима актуелни пример из неурофилозофије, где се често постулира јаз између сопства и мозга. Једна од теза редукциониста је да не одлучујем ја, него мој мозак. Они који заступају дуализам оспоравају пак ту тезу. Међутим, уколико се претпостави да се реч ,ја‘ односи на мене као конкретно живо биће, које том речју упућује на себе, онда према Бекерману нема потребе за конструкцијом такве „конкуренције“ између сопства и мозга. У том случају је и мозак део мене. „[Ш]та говори против претпоставке да одлучујем помоћу свог мозга -

6 Бекерманове цитате превео аутор, Д. С.

7 Немачки: „,das Ich“, „,das Selbst“ или „,ein Selbst“. 
као што и видим помоћу својих очију, дишем помоћу својих плућа и ходам помоћу својих ногу?“ (Beckermann 2012: 38) Ово је свакако компатибилистичко решење интензивно дискутованог проблема, око којег се још увек споре (а око ког ће се вероватно и у будућности спорити) истраживачи из разних научних и филозофских области. Но овде нас не мора занимати да ли је Бекерман овим аргументом у задовољавајућој мери решио тај проблем или не - нама је важније да размотримо предлог да се ограниченом употребом речи ,jа' и ,сопство достигне транспарентност унутар филозофског дискурса.

У реплици на један приговор, који је објављен у истом часопису, а који му је упутио један колега са другог немачког универзитета, ${ }^{8}$ Бекерман оспорава

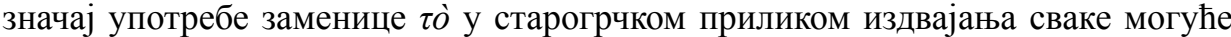
речи и њене хипостазе у засебан предмет, сматрајући да је на тај начин научно мишљење у антици морало скренути са правог пута. Та чињеница „води ка претпоставци да се свуда могу открити којекаква суштаства - суштина једнаког, лепог, доброг еtc.“ (Beckermann 2012: 40) Да се према његовом мишљењу филозофија и наука придржавала одговарајућих придевских и глаголских форми, избегла би многобројне странпутице.

Оно што остаје као „препорука“ Бекермана и других аналитичких аутора ${ }^{9}$ је да се опрезно поступа са једном речју као што је „ја“. По њему је довољно да је ограничимо на случајеве када једна особа именује себе тако што употребљава исказе у којима преко личне заменице у првом лицу изражава одређену пропозицију. Тугендхат то изражава следећом формом: ,ја знам: ја $\varphi$ “, с тим што израз , $\varphi^{‘}$ означава предикат који се односи на неко стање свести (упор. Tugendhat 1979: 50) Дакле, „Ја знам да имам тај и тај осећај“, „Ја знам да видим ту и ту ствар“, „Ја знам да у тренутку мислим овако или онако“ итд. Али исказ као што је овај: „Ја поставља изворно своје сопствено бивство“ или „Ја поставља само себе као ограничено кроз Не-Ја“ по таквој логици нема смисла.

\section{СМИСАО ФИЛОЗОФСКИХ ФОРМИ ГОВОРА О СОПСТВУ}

8 Ради се о Михаел-Томасу Лискеу (Универзитет Пасау).

9 Међу ьима у немачком говорном простору, којем припада Бекерман, треба издвојити име Ернста Тугендхата, чија се предавања о самосвести и самоодређењу с једне стране могу читати као критика традиционалне филозофије, с друге као својеврстан увод у аналитички начин мишљења (види Tugendhat 1979). 
Како се поставити према проблему филозофске употребе речи као што су „ја“ или „сопство“? Да ли прихватити сугестије аналитичких аутора или остати на становишту традиционалних (супстанцијалистичких) теоретичара субјективности? Или постоји можда и трећи пут којим треба кренути уколико желимо адекватно схватити појаве везане за проницање саморефлексивног карактера знања о себи? Ако на овај начин поставимо питања, могуће је претпоставити да сходно заступљеној позицији постоји и посебан дискурс о „jа“ (или „Ја“!) чија логика налаже да се дотични филозоф на известан начин постави према проблему одређења тог феномена - и то тако да се унапред искључи могућност друкчијег схватања, самим тиме и друге позиције. Овде се може употребити и Витгенштајнов концепт језичке игре: правила моје језичке игре траже од мене да се према проблему сопства поставим онако како користим тај израз. Ако сам идеалиста, онда ће ,jа“ бити више од пуке речи, од деиктичког знака који упућује на оног ко говори - оно је самостални феномен чије самоконституисање треба да истражи (идеалистичка) филозофија, нпр. учење о науци или феноменологија. Ако сам аналитички филозоф (посебно онај натуралистичке оријентације), онда ,ја“ као феномен за себе (које идеалисти пишу великим словом) не постоји, јер нема смисла изразу који зависи од контекста говора ${ }^{10}$ приписивати засебно значење - оно што преостаје је анализа употребе те личне заменице у разним говорним ситуацијама. Правила језичке игре идеализма су сасвим друга од правила језичке игре аналитичке филозофије или натуралистичког редукционизма.

Уколико се прихвати плурализам језичких игара и у оквиру филозофије, значи ли то да је филозофија заказала? Да ли је капитулирала пред релативизмом? Како одржати релевантност „захтева за важењем“ као моторну снагу филозофирања, уопште потребу да се бољим аргументом оправда нека теза, ако се допусти плурализам језичких игара, тиме и плурализам правила? Ова питања се не могу одговорити са становишта одређеног филозофског „изма“ - њих би пре требало препустити метафилозофији као вредносно неутралној дисциплини која се бави одређењем структуре филозофског мишљења. ${ }^{11}$ Оно 10 Док са̂м говорим, има смисла да себи припишем тај израз; али исто тако има смисла да га себи припише друга особа која је потпуно различита од мене. Тако и она за себе може рећи да је , ја“.

11 Аутор је такво схватање метафилозофије изложио у засебној публикацији (Smiljanić 2006), с тим што му је од епистемолошке користи био перспективизам као она концепција 
што је овде могуће јесте да се претпостави да је употреба филозофских термина уско везана за светоназорну оријентацију одређеног филозофа, па у светлу тог увида треба бацити поглед на проблем одређења „суштине“ сопства (или њеног негирања, управо у зависности од заузете тачке гледишта).

Из ког разлога идеалиста говори о „Ја“, а аналитички филозоф само о ,ja“(,мени“)? Пошто се сад крећемо на тлу филозофије језика треба преиспитати имплицитну теорију значења, коју претпостављају ове две филозофске оријентације. Тако се у позадини идеалистичких концепција сопства може препознати реалистичко поимање значења. Овај реализам не сме да се помеша са оним реализмом против којег је усмерен управо идеализам, а који бисмо могли назвати онтолошким реализмом (теза о постојању ствари независно од духа). Семантички реализам треба да значи да се предмет на који се упућује неким знаком сматра реално постојећим, нешто што и независно од денотације постоји за себе. Наравно, оно што је означено, денотат, у идеалистичком смислу само је назначен, никако се његова „суштина“ не може исцрпети знаком којим је денотиран. Отуда се ,jа““ овде често пише великим словом, јер оно управо треба да укаже на тај вишак значења - „Ја“ је нешто више од ,ја““ (тачније: од „мене“). Особе А, Б и В које себе означавају речју ,ја“ партиципирају у ономе „Ја“, које је по идеалистима уопште предуслов за самоодређивање особе путем употребе заменице ,ja‘. „Ја“ (писано великим словом) је у том смислу изворнији феномен, ,jа“ (писано малим словом) само изведени. Можда је тиме назначен парадокс: „Ја“ као оно најличније је у суштини безлично! (О томе код Фихтеа сведочи скоро искључива употреба речи ,Ја' у трећем лицу једнине.) Овај (имплицитни) семантички реализам напросто налаже од идеалистичких филозофа да оно што је само назначено термином ,Ја‘ развију у виду засебних теоретских разматрања која у зависности од „додатне“ оријентације аутора могу добити чак и онтолошки предзнак. Ако се пође од идеалистичког становишта, самим тиме прихвати и семантички реализам, онда је скоро логично ${ }^{12}$ да теорије сопства добијају онај формат који је препознат у традицији мишљења од Декарта до немачких идеалиста, без обзира на интерне разлике између

која адекватно може описати позиционални модус филозофског мишљења.

12 Логично у смислу „логике мисаоних форми“, дакле, сходно оној мисаоној форми која се остварује у тој врсти филозофије. Види концепцију такве „плуралистичке“ логике код Ханса Лајзеганга: Leisegang 1951. 
конкретних концепција.

Са друге стране аналитичка филозофија - како је то већ напоменуто - своје корене има у номинализму, па отуда не чуди да је то њена главна семантичка оријентација. Значење речи није нешто самостално, нешто што „Лебди у ваздуху“, оно се не може одвојити од саме те речи. Тако је и смисао индексичког израза ,ja“ да реферише на ону особу која управо користи тај израз - ,jа“ које треба да значи неки принцип за себе (,jа“ које постаје „Ја“) губи према аналитичким филозофима свој смисао. Тим изразом је увек указано на једну (конкретну) особу која користи тај израз у комуникацији са другима, свесна да се он односи само на њу. Та особа уједно разуме разлику између сопствене употребе те речи и њене употребе од стране друге особе. У идеализму је та реч формула идентитета, у аналитичкој филозофији она служи међусобном разликовағу особа: особа А не меша себе са особом Б, иако обе користе израз ,ja‘. Зато постоје други изрази којима се означавају друге особе („ти, „он“, „они“). Колико ти изрази зависе од контекста, види се по томе што једна једина особа може да буде означена свим тим заменицама - она саму себе може ословити („Ја сам ...“), неко други јој се обраћа у директној комуникацији („Ти си ...“ или „Ви сте ...“) или она на индиректни начин бива именована („Он/она је ...“) када две или више особа говори о њој док је одсутна. Због релативности значења тих речи из угла аналитичке филозофије свако засебно разматрање денотата у смислу засебног ентитета се сматра сувишним - зато се одбацује свака еголошка метафизика која хипостазира значење речи. Друго је употреба именица као што су ,човек', ,пас“ или ,кућа', чији денотат се сматра реалним. Из тог разлога су категоријално раздвојене именице и заменице, то су различите врсте речи, самим тиме је и смисао њихове употребе различит. Оно што филозофији преостаје јесте да разграничи те врсте речи с обзиром на њихову функцију и тиме се путем језичке интервенције затворе врата свакој могућој злоупотреби тих речи као што је она у метафизици.

Дакле, ако се пође од различитих претпоставки у филозофском мишљењу као што су семантички реализам и номинализам, резултат тога су сасвим диспаратне концепције сопства: једна која сопство сматра реалним и друга која само реч ,сопство“ сматра употребљивом без претпостављања неког засебно постојећег супстрата. Али шта је онда заиста са сопством? Да ли се оно 
треба ограничити на употребу једне речи или је оно форма знања о себи која је предмет личног искуства? Сада на план ступа метафилозофија, која полази од плурализма филозофских језичких игара и која стога каже: у језичкој игри идеализма реч ,ja“ има другу улогу него у аналитичкој језичкој игри, па је стога и употреба те речи друкчија. Зато је легитимно да се ,jа“ пише великим словом, јер је то оправдано специфичним контекстом употребе, исто као што је легитимно да се ,jа“ пише искључиво малим словом и сматра само синкатегорематским изразом (окамовски изражено: да је само flatus vocis). Оно што није легитимно и није у складу са плуралном логиком филозофије јесте да се једна од ових употреба речи ,jа‘ сматра једино меродавном и на основу тога друга одбацује као неважећа (бесмислена - метафизичка из угла аналитичке филозофије - или редукована - таквом сматрају аналитичку концепцију сопства симпатизери традиционалне филозофије). Главни проблем који се овде поставља је шта неке филозофе наводи на то да се приклоне једној врсти говора о ,ја“, а шта друге супротном дискурсу. Но то више није проблем филозофије већ метафилозофије.

\section{ЗАКЉУЧАК}

Питање да ли се реч ,ja' може писати великим словом или не у светлу претходних метафилозофских разматрања постаје опсолетно. Чак би се могло рећи да је једна од главних заслуга филозофије та да дозвољава проширеље значења одређених речи (наравно не произвољно, већ аргументативно изведено). Некада ти семантички „додаци“ могу постати и део свакодневне употребе те речи. Вероватно ни Бекерман није против обогаћења значења неких филозофски релевантних речи новим нијансама - он само сматра да се увођењем речи ,Јa“ [das Ich] и ,Сопство“ [das Selbst] речник, којим се служе како филозофи тако и нефилозофи у свакодневној комуникацији, није обогатио (упор. Beckermann 2012: 36). Али када би се у филозофији служили само једнозначним речима, када би, дакле, једној речи сви филозофи приписивали исто значење, о чему би онда уопште дискутовали? Не лежи ли изазов, можда чак и драж филозофије у томе да се одређене речи различито употребљавају и на тај начин постају предметом мање или више продуктивних расправа? Можда је фикс-идеја представника филозофских „изама““ да се прихвати један филозофски језик (онај 
којим сами говоре), у којем би сва значења била фиксирана у недвосмисленим дефиницијама и јасно одређена употреба речи односно ситуације, у којима могу бити коришћене, а у којима не - но не би ли то био крај филозофије? У сваком случају, било би то осиромашење филозофског дискурса који живи од семантичких инкомензурабилности али и од семантичких иновација. Иако су јасноћа и сувислост говора идеали којима треба тежити у филозофији, исто тако треба одобравати и подстицати проширивање семантичког хоризонта речи, под условом да се оно изводи промишљено и уз добре аргументе. Уколико би се прихватило овакво схватање, то би могло имати дубокосежне последице за филозофију и конципирање њених будућих задатака.

То се може показати и на даљем промишљању проблема субјективности. Наиме, није искључено - штавише, за препоручити је - да се опробају нове перспективе сагледавања сопства, дакле, да се изађе из уског оквира досадашње филозофске дискусије о том феномену, у којој су, као што је у општим цртама овде показано, доминирале идеалистичка и номиналистичка перспектива. Оно што се може пребацити како идеалистима тако и аналитичким филозофима јесте њихова фиксираност на активну употребу речи ,ja', уопште на номинатив те речи. То се не дешава случајно, јер сопство се овде узима за оно од чега полази мишљење појединца, што је у средишту мишљења, али исто тако као оно од чега крећу његове радње, оно што их конципира („Ја мислим ...“ „Ја чиним то и то ...“, „Ја намеравам да ...“ итд.). Али таква претпоставка само делимично погађа истину; она изоставља из вида ситуације, у којима је угрожен или можда чак и нарушен интегритет и идентитет тога ,jа“. Шта је са оним ситуацијама, где субјект не влада суверено својим мислима, намерама и радњама, другим речима: када се нешто дешава са њим? За такве случајеве језик нам на располагање даје пасивну конструкцију реченице, али исто тако друге форме изражавања сопства, форме као што су „мени“ (датив) или „мене“ (акузатив). Не ради се овде једноставно о преокретању перспективе, у том смислу да се из актива „пребацимо“ у пасив, да више нисмо они који врше, него који трпе неку радњу. Овим се прелази на један засебан начин искушавања сопственог бића који не може адекватно да се прикаже употребом номинатива заменице ,ja‘ и активних глагола - потребно је прећи оквир супстанцијализма и акционизма ${ }^{13}$.

13 „Акционизам“ у смислу давања примата сврсисходним радњама у односу на друге аспекте понашања индивидуе. 
Један такав пример алтернативног мишљења је у својим социјалнопсихолошким истраживањима дао прагматиста Џорџ Херберт Мид, разликујући унутар сопства ,jа“ $[I]$ и „мене“ $[M e]$, укључујући у конституцију сопства и утицај друштва: „То ,jа“ је реакција организма на ставове других; ,мене“ је организирани скуп ставова других које сам човјек усваја. Ставови других конституирају организирано ,мене', а онда човјек реагира на то као неко ,ja‘ .“ (Mead 2003: 167) Занимљив је редослед: прво бива конституисано „мене“, а тек онда реагује ,jа“. Идеалистички свет сопства је тиме преокренут на главу, а тиме се отварају и нове перспективе за филозофију језика. (Приметили су то и неки аналитички филозофи: упор. Tugendhat 1979, 10. и 11. предавање.) Могућа су и феноменолошка разматрања, у којима се промишља патичка димензија конституисања сопства, ${ }^{14}$ рецимо када се субјект препозна као оно што је афективно погођено (примери: „Боли ме“, „Ухватила ме је сета“, „Скаче ми се од среће“ и сл.), а може се чак и мишљење као оно што у традицији конституише сопство описати другим језиком, као дешавање које измиче контроли некад свемоћним сматраног субјекта („Пало ми је на памет“, „Синуло ми је“, „Мучи ме мисао“ итд.). Тиме је назначен задатак којим би се убудуће могла бавити филозофија: да промишља „мене“, а не само ,ја“ да буде предмет њених рефлексија.

\section{ЛИТЕРАТУРА}

Beckermann, Ansgar (2012). Es gibt kein Ich, es gibt nur mich. Information Philosophie.1/12: 35-41.

Berkeley, George (1999). Одабране филозофске расправе. Загреб: КруЗак.

Кант, Имануел (1970). Критика чистога ума. Београд: Просвета.

Leisegang, Hans (1951). Denkformen. 2. Aufl. Berlin: Walter de Gruyter \& Co.

Лок, Џон (1962). Оглед о људском разуму. Београд: Култура.

Mead, George Herbert (2003). Ум, особа, друштво. Загреб: Јесенски и Турк.

14 Као парадигматична се у том смислу могу узети разматрања нове феноменологије Хермана Шмица, у којој се посебан акценат истраживања ставља на афективно искуство субјекта. Види посебно Schmitz 1969, где је реч о „осећајном простору“ [Gefühlsraum] којим је субјект окружен. 
Perry, John (ed.) (2008). Personal Identity. 2nd Edition. Berkeley, Los Angeles, London: University of California Press.

Ryle, Gilbert (1951). The Concept of Mind. 3rd Reprint. London: Hutchinson's University Library.

Smiljanić, Damir (2006). Philosophische Positionalität im Lichte des Perspektivismus. Ein metaphilosophischer Versuch. Marburg: Tectum.

Tugendhat, Ernst (1979). Selbstbewusstsein und Selbstbestimmung. Sprachanalytische Interpretationen. Frankfurt am Main: Suhrkamp.

Фихте, Јохан Готлиб (1976). Учење о науци. Београд: БИГЗ.

Frank, Manfred (Hg.) (1994). Analytische Theorien des Selbstbewusstseins. Frankfurt am Main: Suhrkamp.

Henrich, Dieter (1967). Fichtes ursprüngliche Einsicht. Frankfurt am Main: Vittorio Klostermann.

Husserl, Edmund (1987). Cartesianische Meditationen. Eine Einleitung in die Phänomenologie. 2. Aufl. Hamburg: Felix Meiner.

Шелинг, Фридрих Ј. В. (1988). Форма и принщип филозофије. Рани списи. Београд: Нолит.

Schmitz, Hermann (1969). System der Philosophie. Bd. III,2: Der Gefühlsraum. Bonn: Bouvier.

Damir Smiljanić

\section{THE WORD 'I’ BETWEEN HYPOSTASIS AND REDUCTIONISM PROBLEMS OF THE PHILOSOPHICAL DISCOURSE ON SELF}

\section{Summary}

In this paper the author is reflecting on the status of the words 'I' and 'Self' in the philosophical discourse. By making the difference between two tendencies of dealing with problems of self-consciousness - the idealistic and analytical tendency - he points out two ways to understand 'Self' as a phenomenon. The idealists make a category mistake by transforming the self into a separate entity (hypostasis) that becomes the main philosophical principle in the era of German idealism (for example in Fichte's transcendental idealism); on the other hand 
many representatives of analytic philosophy are criticizing this kind of substantialized usage of words concerning self-consciousness and subjectivity and they are reducing this usage to one-person-situations (one person = one user of the word 'I'). Instead of opting for a singular perspective of understanding the self the author pleads for an expansion of semantic horizons of words we're using for philosophical purposes (this is a metaphilosophical view). Finally he suggests the integration of the affective dimension of our subjective experience into the analysis of Self - the word 'Me' will be an important part of this discourse (in sentences like 'Something happened to me' we can recognize a different character of the phenomenon called 'Self').

Key words: I, Self, idealism, hypostasis, analytic philosophy, reductionism, metaphilosophy, language-game, Me 